\title{
EDITORIAL
}

In October 2017 the journal Photosynthetica commemorated 50 years since its establishment. We thank all who celebrated this with us and paid also tribute to RNDr. Zdeněk Šesták, DrSc., the founder of our journal.

\section{Zdeněk Šesták and Photosynthetica, a tribute*}

\author{
H.K. LICHTENTHALER \\ Plant Molecular Biology and Biochemistry, Karlsruhe Institute of Technology (KIT), University Division, \\ Karlsruhe, Germany, e-mail: hartmut.lichtenthaler@kit.edu
}

On the occasion of the $50^{\text {th }}$ anniversary of the international journal Photosynthetica in 2017 we briefly report on the establishment of this journal and on Dr. Zdeněk Šesták, the renowned researcher of photosynthesis processes who, in cooperation with the Czechoslovak Academy of Sciences, founded this essential science journal in Prague in 1967.

\section{Introduction}

The photosynthesis of green plants is the central and most essential biochemical process on Earth. With the help of absorbed sunlight it transforms inorganic carbon dioxide into sugars and other organic compounds. Human life and that of all other heterotrophic organisms on our planet are only possible due to this basic 'photosynthesis of green plants'. It does not only provide the organic plant products of our food but also evolves oxygen needed for our respiration. In fact, all the oxygen in the air is derived from the light-triggered photosynthetic processes of green plants and algae having evolved in many hundred thousand millenniums of years.

Photosynthesis of green plants and algae is a very complex photochemical and biochemical process consisting of two light reactions and associated electron transport reactions that via photolysis of water delivers both the energy (ATP) and the reduced coenzyme NADPH needed for the assimilation of carbon dioxide and its transfer to sugars in the carbon reduction cycle, known as Calvin-Benson cycle of photosynthetic carbon dioxide fixation. All parts of these processes proceed in special cell organelles of green plants, the chlorophyll containing chloroplasts of leaves and other green plant parts. Due to the very complex nature of this overall process, research in

\section{Establishment of the Photosynthetica journal}

The problems and discrepancy in finding and detecting new research results as well as older original literature on the different aspects of photosynthetic research were fully recognized by Zdeněk Šesták in Prague at the beginning of the $1960 \mathrm{~s}$. He also realized that the lack in communication between scientists performing research in all those photosynthesis has attracted researchers of all fields of science, such as photochemists and biophysicists investigating the photosynthetic light reactions, biochemists studying the enzymatic processes, plant physiologists measuring the $\mathrm{CO}_{2}$ fixation and $\mathrm{O}_{2}$ evolving rates and the light-induced development of the of functional chloroplasts, as well as electron microscopists dealing with the fine structure of chloroplasts and the differential arrangement of the photosynthetic biomembranes, i.e. the photochemically active thylakoids, due to environmental factors. Hence, new results obtained in one of the numerous fields of photosynthesis research were published and widely distributed in many different physical, chemical, biochemical, botanical, and plant physiological journals all over the world. In other words, it was very difficult to detect newly published results and findings in photosynthesis research carried out in one particular field and one country by scientists working either in other fields of photosynthesis research or living in various countries. This problem was even enhanced after World War II due to the strong activation of science research, the development of new investigation methods, and the establishment of new laboratories for photosynthesis research in many countries.

different fields of photosynthesis, a matter that was mainly the result of their research results being published in quite different science journals, such as physical, biophysical, chemical, biochemical, and botanical journals. For this reason, many results were not noticed by other scientists working on different or similar photosynthetic topics. To

\footnotetext{
${ }^{*}$ Written version of a tribute held on October $23^{\text {rd }}, 2017$ on the $50^{\text {th }}$ anniversary celebration of the journal Photosynthetica at the Czech Academy of Sciences, Villa Lanna, Prague.
} 
change this, in the mid-1960ies Zdeněk Šesták came up with the brilliant idea to start a new journal dedicated to all forms of photosynthesis research. There, researchers from all over the world would be able to publish and discuss their latest research results. This should be a photosynthesis journal that would publish the new findings in all fields, such as photochemistry, electron transport, carbon dioxide fixation by whole plants and isolated chloroplasts as wells as matters of pigment biosynthesis and chloroplast development. He continuously discussed this idea with various people and found in Prof. Ivan Málek of the

\section{Zdeněk Šsesták}

Who was Zdeněk Šesták and where did he obtain his education? Zdeněk Šesták was born in Prague on 4 August 1932. In the 1950ies he studied Plant Physiology and Anatomy at the famous Charles University in Prague and wrote his M.Sc. thesis. In 1958, he joined the Institute of Experimental Botany of the Czechoslovak Academy of Sciences in Prague and in 1961 he presented his Ph.D. dissertation on "Chlorophyll Amount and Photosynthetic Rate". Zdeněk Šesták continued his research in the "Laboratory of Water Relations and Photosynthesis" of the Czech Academy of Sciences headed by Dr. B. Slavik. There, he investigated the relationships between leaf age, chlorophyll contents, and photosynthetic activity. This research he later comprised in his D.Sc. dissertation "Chlorophyll and Photosynthetic Activity during Leaf Ontogenesis". Moreover, this topic was also the basis for the internationally well-known book "Photosynthesis during Leaf Development" which he wrote together with several colleagues and which was jointly published by Academia, Prague, and Dr. W. Junk Publisher, Dordrecht, in 1985. This book was a great success and well accepted by the scientific community because it not only contained interesting new research results but also proved to be an essential and excellent reference book and a rich source for numerous older observations in photosynthesis research having been precisely summarized in this book. The latter stimulated new endeavors in photosynthesis research, as has the Photosynthetica journal since 1967. Even during the times of the 'cold war' this first journal open to all aspects of photosynthesis research was available both in Western and Eastern countries. In addition, he edited the book "Plant Photosynthetic Production. Manuals of
Czechoslovak Academy of Sciences a very influential supporter to create an international photosynthesis journal. Thus, in 1967 the journal Photosynthetica was established by the Czechoslovak Academy of Sciences with Ivan Málek as its Editor-in-Chief and Zdeněk Šesták as the Executive Editor. This was a great achievement, an act of pioneering, for which the scientific community is very grateful to Zdeněk Šesták and also to Ivan Málek who had the insight to promote this new journal project. Some of these developments that led to the foundation of Photosynthetica are described in Šesták (1992).

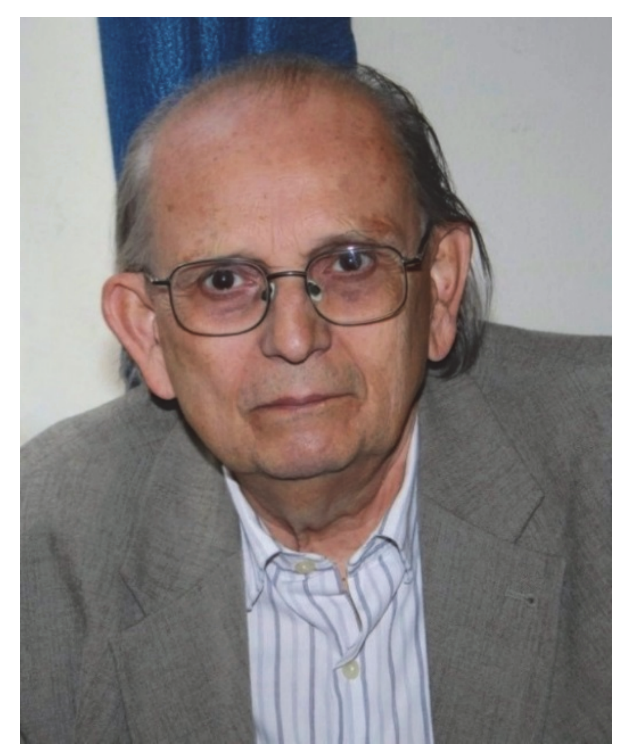

Fig. 1. Zdeněk Šesták, Editor-in-Chief of Photosynthetica (source: Photosynthetica 55, 2017).

Methods" (Dr. W. Junk, Publishers, Den Hague, 1971). Moreover, he wrote in detail the "History of Photosynthesis Research in Czechoslovakia" (Šesták 1992). In fact, Zdeněk Šesták was a pioneer and great promoter of science communication concerning all aspects of photosynthesis research and via this activity he also efficiently stimulated new research in photosynthesis. After a life as a dedicated scientist and meritorious Editor-in-Chief of Photosynthetica he passed away in 2008 (Květ and Šetlík 2008).

\section{Zdeněk Šesták and the first International Photosynthesis Congress}

A second pioneer in prompting the international cooperation, exchange, and discussion of photosynthetic research results was Professor Helmut Metzner, Tübingen, who, in the late 1950ies, had been a postdoctoral fellow in Melvin Calvins Laboratory in Berkeley, California. After returning to Germany he kept in touch with the colleagues in the USA performing research in photosynthesis and with other postdoctoral fellows he had met there and who had returned to Europe. He also started contacting many colleagues of European photosynthesis laboratories including those in Eastern Europe. He got to know Zdeněk Šesták and in 1967 he became a member of the editorial 
board of the newly founded Photosynthetica journal. In May 1968, H. Metzner successfully organized the first International Photosynthesis Congress in Freudenstadt, Black Forest, Germany. He had been very active in raising funds to organize that congress and to support various Eastern European colleagues with travel grants enabling them to participate. In fact, this photosynthesis congress in Freudenstadt was the first international science congress in Europe after the World War II, where scientists from Eastern and Western Europe as well as the USA and Japan met and openly discussed their photosynthetic research results. For many of us this congress was a good chance to get acquainted with our colleagues from many different countries and in particular with various colleagues from Poland, Hungary, Czechoslovakia, and also from Russian photosynthesis laboratories where some of the Eastern European colleagues had studied and obtained their Ph.D. At this congress, many scientists familiar with each other from the literature met for the first time and openly discussed all questions in photosynthesis research as well as controversial problems. From this congress essential impulses came for an international science cooperation, in particular for photosynthesis research. In fact, since 1968 these International Photosynthesis Congresses have been held in different countries every three years (see e.g.

\section{Cooperation with Zdeněk Šesták}

In the mid-1980ies with financial support by the German Research Council I was able to invite first Zdeněk Šesták and later his colleague Jiří Čatský to Karlsruhe for seminars and discussions, whereas I was able to visit the Institute of Experimental Botany in Prague. In this scientific exchange Zdeněk Šesták also included his younger colleagues Jiř́ Šantrůček and Pavel Šiffel, who worked in a photosynthesis research institute of the Czechoslovak Academy of Sciences in České Budějovice. They also came to Karlsruhe and this resulted in joint research endeavors and several joint publications, e.g. on the differential photosynthetic activity and pigment composition of green and aurea plants (Šiffel et al. 1993). When in June 1988 I organized the first international Chlorophyll Fluorescence Symposium in Bad Honnef, Germany, I could invite Zdeněk Šesták and Pavel Šiffel, with the financial help of the W.E. Heraeus Foundation, Hanau, Germany, to participate. There, both gave presentations, one of them on "Changes in chlorophyll fluorescence during leaf development" and the other on "Low temperature fluorescence of chloroplasts". Both contributions appeared in the book Applications of Chlorophyll Fluorescence, published by Kluwer Academic Publishers, 1988 (Šesták and Šiffel 1988; Šiffel and Šesták 1988). After the 'velvet revolution' in 1989, Jiří Šantrůček and Pavel Šiffel - with the activation and support by Zdeněk Šesták and myself - were able to organize the symposium "Photosynthesis and Stress" in České Budějovice in 1991, which brought many scientists from the East and West
Govindjee and Knaff 2006) and finally led to the formation of the International Photosynthesis Society.

With a special personal travel grant by Helmut Metzner, Zdeněk Šesták received - despite strict travel limitations to Western countries - the permission of his country to participate in the Freudenstadt photosynthesis congress in 1968. There, he personally met many colleagues from the worldwide photosynthesis community, in particular those who had become members of the editorial board of Photosynthetica in 1967. Also, it was this congress where I first met him in person. He was a very open-minded, welleducated colleague with an enormous knowledge of older photosynthetic literature as well as a profound knowledge of European history and art. We discussed many different topics, in German or in English, and we had similar ideas and mutual interests of how to perform future photosynthetic research. This was the starting point of a lifelong friendship. We kept in contact, and from time to time we got together on small topical photosynthesis workshops in Germany or other Western European countries. Due to his position as the executive editor of Photosynthetica, Zdeněk Šesták was able to travel more often to Western European countries because he also had to visit Dr. W. Junk Publishers, The Hague, which - since 1969 - distributed Photosynthetica in the Western countries.

together to present and discuss their results. The major papers from this symposium were published in a special issue of Photosynthetica. Zdeněk Šesták had already, before and even more intensively after the 'fall of the iron curtain', arranged that about 13 special issues of Photosynthetica were edited with selected papers of particular photosynthesis meetings held in different places of Poland, Bulgaria, Hungary, the Czech Republic, and

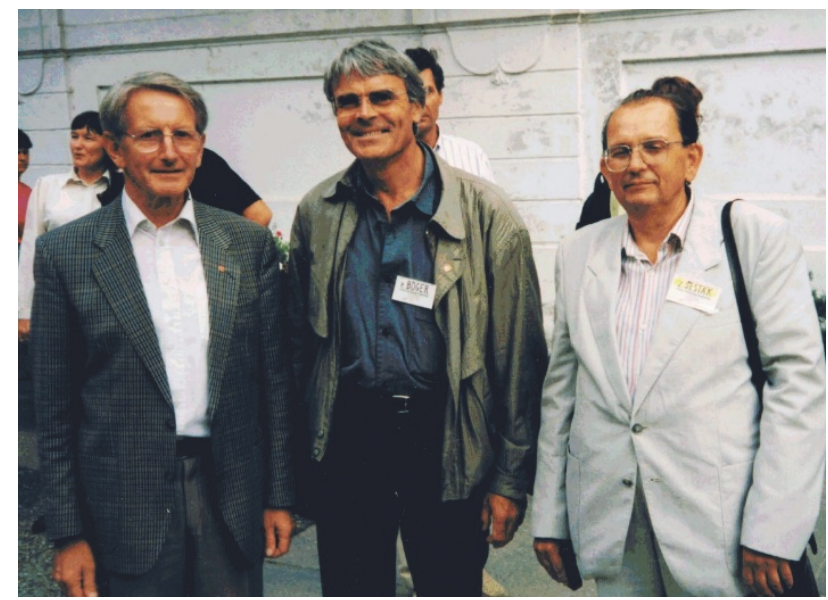

Fig. 2. Zdeněk Sesták, editor-in-chief of Photosynthetica (right), with colleagues Hartmut Lichtenthaler (left), Karlsruhe, and Peter Böger (center), Konstanz, on the symposium "Photosynthesis and Stress" in České Budějovice, Czech Republic, in 1991. (source: Hartmut Lichtenthaler). 


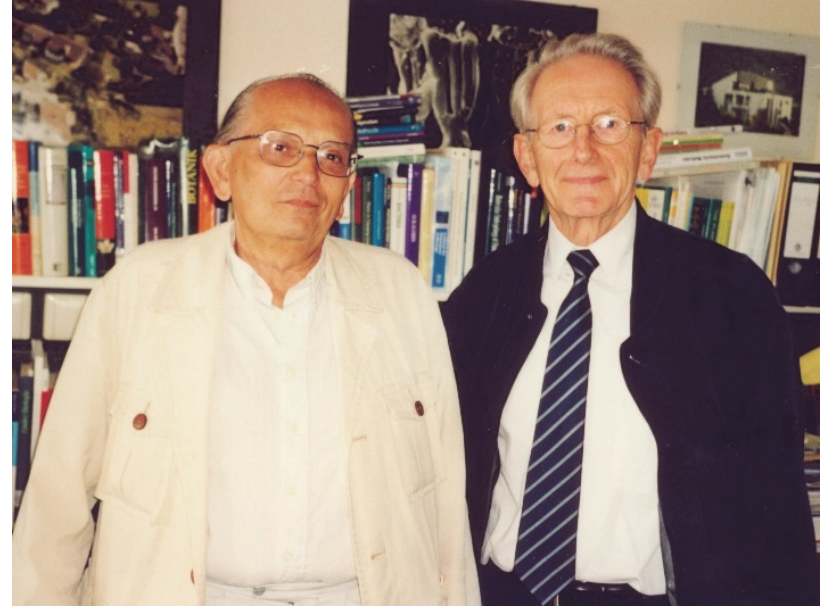

Fig. 3. Zdeněk Sesták (left) in 2000 in Karlsruhe in the office of Hartmut Lichtenthaler. (source: H. Lichtenthaler).

Germany. Thus, Photosynthetica always formed - at times of the cold war and more enhanced after the fall of the iron curtain - a bridge of communication and exchange of photosynthetic findings between the Eastern and Western countries and beyond.

Zdeněk Šesták did not want to publish obituaries in Photosynthetica, when well-known colleagues of our world-wide photosynthesis community had passed away. However, in connection with a special photosynthesis symposium this was possible. Thus in 2003, when his former Ph.D. student and my part-time coworker Dr. Pavel Šiffel, a promising Czech photosynthesis researcher, died much too early in a car accident, he gave me the advice: "When you arrange a special symposium in honor of him, the scientific contributions to this symposium will be published in Photosynthetica together with an article on

\section{Photosynthetica and Photosynthesis Research}

Since its foundation in 1967, Photosynthetica served the scientific photosynthesis community in an excellent way by publishing topical research articles and review papers. It also stimulated photosynthesis research by providing valuable information on new books and newly arising methods of scientific investigation in particular fields of photosynthesis research. In a free world without political limitations, Photosynthetica would have become the leading and only journal of photosynthesis research. Many manuscripts came in from laboratories of various foreign countries. Yet, the political tensions between East and West in the times of the cold war as well as the limited economic resources restricted the normal development of Photosynthetica. In 1969, the world-wide distribution of Photosynthetica, except for the so called 'socialistic countries', was given to Dr. W. Junk Publishers, The Hague, Netherlands, in order to guarantee a fast distribution. This distributor successfully advertised this journal and, as a consequence, the edition increased considerably. him". And this photosynthesis symposium was then arranged by Dr. Jiři Šantrůček in České Budějovice in 2004 and an article on "Pavel Šiffel (1954-2003) or life full of chlorophyll”, written by Květ et al. (2005), appeared in Photosynthetica together with several papers on photosynthetic topics presented at that symposium. Zdeněk Šesták was a very kind and agreeable colleague and friend. He was always ready to take over additional commitments. In 2000 he gave an invited lecture at the University of Karlsruhe (Fig. 3).

In the 1990ies I had cooperated with several Czech research laboratories of the Czech Academy of Sciences and also Czech universities. And in 2004, when I was awarded the Gregor Mendel Medal of the Czech Academy of Sciences, naturally it was Zdeněk Šesták who held the laudatio speech (Fig. 4).

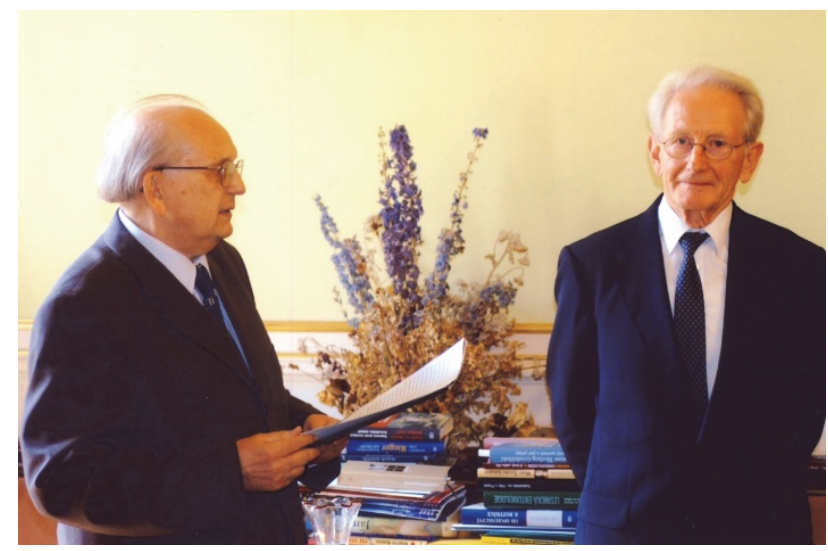

Fig. 4: Zdeněk Šesták (left) in 2004 giving a laudatio speech for Hartmut Lichtenthaler (right) at the Czech Academy of Sciences, Prague. (source: H. Lichtenthaler).

However, the number of issues, i.e. the number of printed pages per year, could not follow the large international demand, because it needed, besides the permission of the Czech Academy, also the permission of the authorities of the then Communist regime. Usually, this permission was given with a delay, a result, at least at certain times, of the limited availability of printing materials in the Czechoslovak Republic. Thus, various reviewed and accepted manuscripts had to wait for printing because the total number of printed pages per year did not as readily increase as did the number of submitted good manuscripts. This problem did not allow a fast and timely publication of accepted papers. Zdeněk Šesták was quite unhappy about this unsatisfactory situation as he complained to me on our occasional meetings.

In this situation, Dr. W. Junk Publishers, which were responsible for the worldwide distribution of Photosynthetica, informed Zdeněk Šesták in 1977 and 1978 that they intended to start another photosynthesis journal, if 
Photosynthetica would not able to considerably increase the number of printed pages and issues per year. However, the permission from the Czechoslovak authorities came too late. As a consequence, in 1980, Dr. W. Junk Publishers started the new journal "Photosynthesis Research" that was also well accepted by the photosynthesis community. Part of these problems and developments were reviewed in Govindjee et al. (2002). Yet, due

\section{Zdeněk Šesták as editor}

Zdeněk Šesták was an excellent editor. His main endeavor and concern as Executive Editor and later as Editor-inChief of Photosynthetica was to stimulate scientific discussion and exchange as well as to activate his colleagues to perform new experiments using novel methods in order to progress and enhance our knowledge in the different fields of photosynthesis research. And this goal he approached with great enthusiasm and he reached it with great personal activities, energy, endurance and his high intellectual capabilities. From the very beginning, Photosynthetica did not only publish original as well as review papers, but also listed and reviewed books dealing with particular photosynthetic topics, provided information on new methods applicable in photosynthesis research. And in this way Zdeněk Šesták gave decisive impulses for younger scientists who were starting their research in photosynthesis.

As a critical reviewer of submitted manuscripts, he encouraged young scientists and colleagues to improve their manuscripts, gave advice on what additional experiments were required to come to a clear-cut conclusion. He corrected the English and shortened lengthy sentences or

\section{The editorial board}

It is amazing how Zdeněk Šesták, in 1967 managed to interest so many renowned photosynthesis researcher from other countries in a membership of the editorial board of the newly launched Photosynthetica journal, such as M.C. Anderson (Canberra, Australia), M. Avron (Rehovot, Israel), C.S. French (Stanford, USA), A.A. Krasnovsky (Moscow, Soviet Union), W. Larcher (Innsbruck, Austria), Helmut Metzner (Tübingen, Germany), A. Moyse (Orsay, France), A.A. Shlyk (Minsk, Soviet Union), C. Sironval (Sint Truiden, Belgium), H. Tamiya (Tokyo, Japan), H.I. Virgin (Göteborg, Sweden), C.P. Wittingham (London, UK) and various others. These colleagues certainly helped Photosynthetica into a successful start. Yet, to actively integrate all of them in the daily routine of reviewing submitted manuscripts was not easy as a result of the rather long-time periods for sending out manuscript copies and returning reports by surface mail and airmail. Thus, a major part of the reviewing had to be achieved by his Czech colleagues.

In the $1980 \mathrm{~s}$, several members of the international editorial board of Photosynthetica had passed away, others had retired. Yet, Zdeněk Šesták could not change or to the activities of Zdeněk Šesták who personally knew a large number of scientists in photosynthesis research, Photosynthetica continued to be an essential journal of new results in photosynthesis. From its start in 1967 up to today, Photosynthetica has been open for publishing all aspects of photosynthetic research, although manuscripts on the physiological and ecological side of photosynthetic processes seem to dominate these days.

paragraphs in order to increase the readability and understanding of the main scientific message of the papers. This was particularly carried out with manuscripts from countries where science was not yet so well developed. In addition, he did not simply reject manuscripts, as is done by many other scientific journals. He always gave advice how to improve a manuscript, which additional experiments and results were needed in order to come up with clear-cut, significant proves and a new manuscript version that might be acceptable. In this way, he served the international photosynthesis community and at the same time improved the standard of the Photosynthetica journal. He also was an excellent proof-reader of articles. Taken all together, Zdeněk Šesták was a meritorious, demanding, and dedicated editor. All this was implemented in his endeavor to increase the international value and standing of Photosynthetica. In fact, that is the goal Zdeněk Šesták lived for. Photosynthetica was his "child" and life. Even his high interests in digging up new historical findings as well as the interrelationship of European and Czech history ranked secondary.

replace board members as this had to be agreed on, not only by the Academy but also by the political authorities. For a long time he had wanted me on the board of Photosynthetica since I had often reviewed various submitted manuscripts. Only after the "velvet revolution" in his country in November 1989, he was free to select new board members from different countries, colleagues who could actively participate in the evaluation and editing of manuscripts. Then in 1991, I became a member of the editorial board until 2005. In fact, from 1992 up to the $25^{\text {th }}$ anniversary of Photosynthetica he had appointed 15 new board members, 12 from different, mostly European countries, and also three Czech colleagues (Table 1). In addition, he confirmed the four Czech colleagues Jiří Čatský and Bohdan Slavik from Prague as well as Ivan Šetlík and Jan Květ from Třeboň who, in the first 25 years of Photosynthetica, had done so much of the reviewing work. With the invention and introduction of electronic communication the reviewing process of manuscripts became much faster. Now manuscripts could be sent out and the reviews transmitted very quickly via e-mail or on-line system. 
Table 1. New members of the editorial board of Photosynthetica in 1992 at its $25^{\text {th }}$ anniversary.

\begin{tabular}{ll}
\hline European colleagues & Czech colleagues \\
\hline A.Y. Borisov (Moscow) & J. Čatský (Prague), since 1967 \\
J.M. Briantais (Orsay) & B. Slavík (Prague), since 1967 \\
M.L. Champigny (Orsay) & I. Šetlík (Treboň), since 1967 \\
G. Forti (Milano) & J. Květ (Brno, Třebon̆), since 1967 \\
$\begin{array}{l}\text { P. Hoffmann (Berlin) } \\
\text { P.G. Jarvis (Edinburgh) }\end{array}$ & L. Nátr (Prague) \\
A. Laisk (Tartu) & J. Pospíśilová (Prague) \\
H.K. Lichtenthaler (Karlsruhe) & D. Sofrová (Prague) \\
O. Machold (Gatersleben) & \\
G.C. Papageorgiou (Athens) & \\
W.J. Vredenberg (Wageningen) & \\
S. Wieckowski (Kraków) & \\
\hline
\end{tabular}

\section{Photosynthetica today}

On its $50^{\text {th }}$ anniversary, Photosynthetica is run again by a new group of internationally renowned scientists who serve as Associate Editors and editorial board Members. Since 2012 Photosynthetica has been edited by Helena Synková as editor-in-chief and since 2006 by Ivana Štětinová as executive editor (Synková 2017). Both have excellently managed to keep Photosynthetica going, to keep up its standard and even to increase its impact factor. We from the worldwide photosynthesis community would like to congratulate and thank both of them for their great service for Photosynthetica and for our scientific community. Zdeněk Šesták, who already passed away in 2008 , would be really happy and proud of them if he could be here at this $50^{\text {th }}$ anniversary celebration and see that his beloved Photosynthetica journal is fully functional due to their sophisticated endeavors. And we also want to congratulate and thank the Czech Academy of Sciences for its continuous agreement to publish this fine international journal.

\section{Final remarks}

H.K. LICHTENTHALER (Karlsruhe)

Both Photosynthetica and Zdeněk Šesták have served a great purpose and received magnificent merits as well as international recognition. Today, on its $50^{\text {th }}$ anniversary, we wish Photosynthetica, this excellent international photosynthesis journal, a prosperous future. May it continue to excellently serve our large world-wide photosynthesis community as it did in the past 50 years. Let me express my best wishes for this journal with a Latin name in a Latin phrase: "Photosynthetica, vivat, crescat et floreat!"

Acknowledgements: I wish to thank Ivana Štětinová, MSc., Prague, for providing me valuable article copies on Photosynthetica and of papers of Zdeněk Šesták. Thanks are also due to Profs. Jan Květ and Dr. Jiří Šantrůček, Česke Budějovice, for additional information.

\section{References}

Govindjee, Šesták Z., Peters W.R.: The early history of Photosynthetica, Photosynthesis Research and their publishers. Photosynthetica 40: 1-11, 2002.

Govindjee, Knaff D.B.: International Photosynthesis Congresses (1968-2007). - Photosynth. Res. 89: 1-2, 2006.

Květ, J., Šetlík, I.: Zdeněk Šesták, 4. August 1932 - 14. November 2008 (Obituary). - Photosynthetica 47: V-VII, 2009.

Květ, J., Durchan, M., Roháček, K. et al.: Pavel Siffel (19542003) or life full of chlorophyll. - Photosynthetica 43: 323-328, 2005.

Šesták Z.: History of photosynthesis research in Czechoslovakia. - Photosynthetica 27: 1-37, 1992.

Šesták Z., Šiffel P.: Changes in chloroplast fluorescence during leaf development. - In: Lichtenthaler H.K. (ed.): Applications of Chlorophyll Fluorescence. Pp. 85-91. Kluwer, Academic Publ., Dordrecht - Boston - London 1988.

Šiffel P., Šesták Z.: Low temperature fluorescence spectra of chloroplasts: methodical aspects and possible applications. In: Lichtenthaler H.K. (ed.): Applications of Chlorophyll Fluorescence. Pp. 55-61. Kluwer Academic Publ., Dordrecht Boston - London 1988.

Šiffel P., Šantrůček J., Lang M. et al.: Age dependence of photosynthetic activity, chlorophyll fluorescence parameters and chloroplast ultrastructure in aurea and green forms of Nicotiana tabacum Su/su mutant. - Photosynthetica 29: 81-94, 1993. Synková H.: Editorial. - Photosynthetica 55: 1-5, 2017. 